\title{
Tinjauan fikih dan astronomis penyatuan matla': menelusuri pemikiran M.S. Odeh tentang ragam penyatuan matla'
}

\author{
Muh. Nashirudin \\ Fakultas Syariah dan Ekonomi Islam IAIN Surakarta \\ E-mail:din_ima@yahoo.com
}

The basis of calendar unification or matla'constitutes one of the most significant issues relating to the unification effort of Hijra calendar. The popular basis of unification, so far, is based on the union of regional and global matla' The division of matla to regional and global matla is now no longer accurate because it can not accommodate the Hijra calendar pooling ideas in the Islamic world. This paper discusses one of the leading International astronomy thought, Mohammad Shawkat Odeh on varieties of matla' unification. He divided the principle of matla' unification in to five forms: unification of global matla' (one matla' for the whole world); the unity of matla' in the regions corresponding visibility of hilal; the unity of matla' in a similar area of visibility of hilal; the unity of zonal/partial matla'; and the unity of local matla'. Odeh's thought on the various divisions of matla' constitutes new thinking on the concept matla' astronomical calculations. He also has presented more detailed thoughts on the division of matla' rather than the others.

Salah satu persoalan yang perlu untuk diselesaikan berkaitan dengan usaha penyatuan kalender hijriah adalah pilihan atas prinsip penyatuan matla'. Prinsip penyatuan matla' yang selama ini dikenal adalah penyatuan matla' regional dan penyatuan matla' global. Pembagian penyatuan matla' dengan penyatuan matla' regional dan global saat ini sudah tidak lagi akurat karena tidak dapat mengakomodasi pemikiran penyatuan kalender hijriah di dunia Islam. Tulisan ini membahas pemikiran Mohammad Shawkat Odeh, salah seorang tokoh falak Internasional, tentang ragam penyatuan matla' Ia membagi prinsip penyatuan matla' dalam 5 bentuk; a. penyatuan matla' global (satu matla' untuk seluruh dunia), b. kesatuan matla' dalam wilayah yang bersesuaian visibilitas hilalnya, c. kesatuan matla' dalam wilayah yang serupa visibilitas hilalnya, d. kesatuan matla'zonal/parsial, dan e. kesatuan matla' lokal. Pemikiran Odeh tentang ragam pembagian matla' ini bisa dikatakan sebagai pemikiran yang baru tentang konsep mat \{la' karena memberikan sentuhan perhitungan astronomis yang lebih besar dibandingkan pemikiran- 
ljtihad, Jurnal Wacana Hukum Islam dan Kemanusiaan, Vol. 12, No. 2, Desember 2012: 179-192

pemikiran tentang matla' sebelumnya yang banyak dihubungkan dengan konsep-konsep geografis semata (semisal satu wilayah iklim, tinggi rendah wilayah) atau bahkan dihubungkan dengan konsep lain yang tidak memiliki hubungan sama sekali dengan persoalan astronomis (semisal masafah al-qasr). Ragam penyatuan matla' yang disampaikan Odeh juga lebih rinci dibandingkan pemikiran lain yang hanya membagi penyatuan matla' pada matla' global dan matla' fi wilayah al-bukmi.

Keywords: Unification of matla'; Visibility of the new moon; Various division of matla'; Astronomy

\section{Pendahuluan}

Persoalan yang sering menjadi perdebatan dalam masalah penentuan awal bulan kamariah di dunia Islam secara umum dan di Indonesia secara khusus adalah perdebatan antara penganut metode hisab dan rukyah. Masing-masing penganut metode tersebut merasa bahwa metodenyalah yang paling absah secara syari' dan sesuai dengan prinsip-prinsip dalam astronomi.

Pada tataran tertentu, kedua metode tersebut masih tetap meninggalkan persoalan yang belum terpecahkan dan sering menjadi kontroversi. Di Indonesia, metode hisab misalnya, sampai saat ini masih terbagi dalam dua kutub besar; hisab wujudul hilal dan hisab imkanurrukyah. Hisab wujudul hilal mensyaratkan masuknya bulan baru hijriah pada dua hal, yakni terjadinya konjungsi sebelum terbenamnya Matahari (ijtima', qabl al-ghurūb), dan pada saat terbenam Matahari piringan atas Bulan berada di atas ufuk (bulan baru telah wujud). Inilah yang dipakai oleh Muhammadiyah dalam sistem hisabnya sebagaimana disebutkan dalam Pedoman Hisab Muhammadiyah (Tim Majelis Tarjih dan Tajdid PP Muhammadiyah, 2009: 78). Sementara itu, hisab imkanurrukyah selain mensyaratkan ijtimā, qabl al-ghurūb, masuknya bulan baru hijriah juga didasarkan pada posisi hilal yang mungkin untuk dilihat. Artinya, awal bulan baru hijriah didasarkan pada kenampakan hilal yang sebenarnya (Azhari, 2007: 110; Ichtijanto, 1981: 99-100). Sistem hisab imkanurrukyah inilah yang kemudian melahirkan berbagai kriteria visibilitas hilal. Beragamnya kriteria visibilitas hilal dan belum adanya kesepakatan tentang kriteria visibilitas hilal yang akan dipakai di Indonesia inilah yang menjadi salah satu alasan penganut hisab wujudul hilal untuk menolak hisab imkanurrukyah. Di sisi lain, penganut hisab imkanurrukyah menganggap bahwa kriteria wujudul hilal merupakan kriteria yang tidak dapat dibuktikan secara empiris ilmiah. 
Metode rukyah pada beberapa kasus juga menimbulkan kontroversi yang tidak kalah serius di Indonesia. Kesaksian teramatinya hilal di Cakung pada awal bulan Ramadan 1433 H merupakan kasus controversial terbaru yang terjadi dalam permulaan bulan hijriah di Indonesia. Di satu sisi, kesaksian teramatinya hilal seperti ini dianggap sebagai sesuatu yang absah dalam pandangan fikih karena dilaporkan oleh seorang pengamat yang adil dan dilakukan di bawah sumpah. Artinya, secara syar'i seolah tidak ada alasan untuk menolak kesaksian teramatinya hilal pada kondisi tersebut. Akan tetapi, di sisi lain, kesaksian tersebut dianggap tidak memenuhi kriteria-kriteria ilmiah dalam ilmu falak modern. Kekurangakuratan sistem hisab yang dipakai oleh pengamat, kesalahan dalam menentukan posisi hilal, posisi hilal yang masih di bawah ambang batas teramatinya hilal dalam kriteria visibilitas hilal di Indonesia dan di dunia Internasional dan tidak adanya bukti empiris teramatinya hilal pada saat itu karena laporan menyebutkan bahwa hilal teramati dengan mata tanpa alat menjadi beberapa alasan tidak diterimanya laporan termatinya hilal di Cakung.

Terlepas dari persoalan perdebatan antara penganut metode hisab dan rukyah, sesama penganut hisab ataupun sesama penganut rukyah, persoalan lain yang juga sering menimbulkan persoalan adalah tentang keberlakuan rukyah dan hisab atau yang dikenal dengan keberlakuan matla'. Sampai batas wilayah manakah sebuah rukyah atau hisab dapat diberlakukan dan batas apakah yang dipakai untuk menyatukan sebuah matla' merupakan persoalan yang juga layak untuk didiskusikan.

Tulisan ini hendak melihat salah satu hasil pemikiran Mohammad Shawkat Odeh, salah seorang tokoh ilmu falak di dunia islam, tentang ragam penyatuan matla'. Pemikiran tentang ragam penyatuan matla' yang disampaikan oleh M. S. Odeh sangat penting untuk disampaikan karena pembagian penyatuan matla'yang dilakukannya bisa dikatakan sebagai sebuah pemikiran yang baru dalam khazanah pemikiran ilmu falak di dunia Islam.

\section{Biografi singkat M. S. Odeh}

Nama lengkapnya Ir. Muhammad Syaukat 'Audah (di dunia Internasional lebih dikenal dengan nama Mohammad Shawkat Odeh). Dalam homepage (bttp:/ / wmw.geocities.com/ capecanaveral/ 1092/ index. html) nya, Odeh mengatakan bahwa ia berasal dari Nablus, Palestina dan lahir di kota Kuwait, 6 Maret 1979. Ia tumbuh besar di kota Amman ibukota negara Jordan. Ia 
menyelesaikan studi Mekanik dan Engineering di Universitas Jordan, Fakultas Sains dan Teknologi pada tahun 2002. Di umurnya yang menginjak ke-20, tahun 1998, Odeh mendirikan sebuah lembaga penelitian dan observasi hilal ICOP (Islamic Crescents' Observation Project). Hingga saat ini, lembaga tersebut memiliki ratusan ilmuwan yang terdiri dari pakar ilmu falak dan individu-individu yang intens dalam penelitian dan pengkajian hilal dari berbagai negara di dunia.

Odeh (2004: 2) mengatakan beberapa hal yang mendorongnya mendirikan ICOP. Adanya perbedaan di antara umat Islam dalam memulai bulan hijriah baru, terutama Ramadan, Syawal, dan Zulhijjah, komentar sebagian orang tentang tidak akuratnya ilmu hisab kontemporer dan diterimanya laporan pengamatan hilal di saat hilal seharusnya tidak teramati sangat menggelisahkan Odeh dan mendorongnya untuk meneliti kemungkinan kesalahan dalam memulai bulan baru di Yordania. Hal tersebut dilakukan dengan mengumpulkan surat kabar yang terbit antara tahun 1953-1999, meneliti pengumuman pemerintah Yordania dalam memulai bulan Ramadan, Syawal dan Zulhijjah kemudian membandingkannya dengan permulaan bulan baru yang seharusnya, sesuai dengan perhitungan hisab kontemporer. Tugas itulah yang kemudian diemban oleh ICOP dan menghasilkan kesimpulan yang sangat mengejutkan. Diantara hasil penelitian tersebut adalah;a. untuk bulan Ramadan tahun 19541999 yang berjumlah 47 bulan, 60\% (28 bulan) diantaranya bulan baru dimulai padahal hilal mustahil dirukyah (di bawah ufuk), 36\% (17 bulan) hilal tidak mungkin dirukyah, dan hanya 1\% (1 bulan) bulan mungkin dirukyah dengan alat optik dan 1\% (1 bulan) mungkin dirukyah dengan mata telanjang. Yang juga mengejutkan adalah bahwa permulaan baru di saat-saat itu selalu ditetapkan dengan adanya laporan keberhasilan rukyah. b. untuk bulan Syawal (47 bulan), 68\% (32 bulan) diantaranya hilal mustahil dirukyah, 30\% (14 bulan) hilal tidak mungkin dirukyah, dan hanya 2\% (1 bulan) hilal mungkin dirukyah dengan alat optik. c. Untuk bulan Zulhijjah (48 bulan), dalam hal ini pemerintah Yordania selalu mengikuti Arab Saudi, hasilnya adalah 35\% (17 bulan) hilal mustahil dirukyah, 44\% (21 bulan) hilal tidak mungkin dirukyah, dan 21\% (10 bulan) hilal mungkin dirukyah 6 bulan diantaranya dengan alat optik dan 4 bulan dengan mata telanjang.

Odeh saat ini juga merupakan bagian dari anggota tim Arab Union for Astronomy and Space Sciences (AUASS), yang fungsi dari organisasi ini adalah menetapkan waktu salat dan 
melaksanakan rukyatul hilal. Selain itu, Odeh telah mengikuti berbagai seminar internasional dalam bidang ilmu falak dan juga telah membuat sebuah software (Accurate Times/al-Mawääit ad-Daqiqah) yang mampu menghitung waktu-waktu salat, imkanur rukyah hilal, arah kiblat, dan waktu terbit serta tenggelam bagi matahari dan bulan yang telah digunakan di berbagai belahan dunia (Al-Amin, 2008). Program Odeh ini secara resmi digunakan sebagai alat penentu imkanurrukyat dan kalender hijriah di Yordania dan Aljazair.

Di antara karya-karya Odeh yang berkaitan dengan ilmu falak yang sebagian besarnya diunduh dari website ICOP adalah:al-Farq Bain al-Hilāl wa Tawallud al-Hilāl,al-Hiläl Bain Hisābät al-Falakiyyah wa ar-Rukyah, Taqwim Nasb al-Khata' fi Tahdid Awäil al-Asyhur al-Hijriyyah (fi alUrdun), "New Criterion for Lunar Crescent Visibility" yang merupakan artikel dalam Nidhal Guesseoum \& Mohammad Odeh (ed.), Aplications of Astronomical Calculations to Islamic Issues,

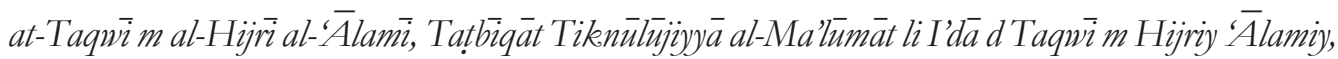
Al-Farq Bain Atwā r al-Qamar al-Markaziyah wa as-Sathiyyah, at-Taḥwi lMa Bain at-Taqwimain

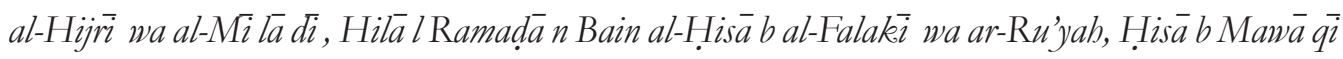

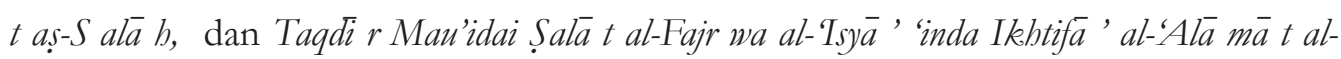
Falakizyyah fi al-Mantiqah Mà Bain Khattai 'Ard $48.6^{\circ}$ wa $66.6^{\circ}$. Karya terakhirnya yang berkaitan dengan tema penyatuan matla' berjudul Ikbtilā f al-Matāa li', al-Manā tiq al-Musytarakah bi

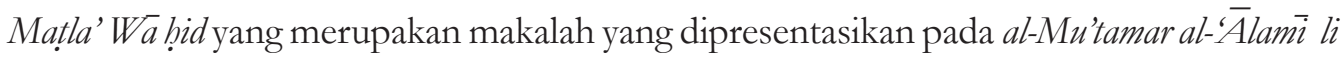
Is $\backslash$ bà t asy-Syubū ral-Qamariyyah 'inda 'Ulamā' asy-Syari' ah wa al-Hisā b al-Falakì yang diadakan oleh Komite Fiqh Islam (al-Majma' al-Fiqhì al-Islà mi) OKI (Räbitah al-'ÁAlam al-Islà mì di kantor OKI, Mekah, pada tanggal 19-21/03/1433 H/11-13/02/2012 M.

\section{Konsep matla'dalam fikih dan astronomi}

Perbedaan tentang penyatuan matla' dalam sejarah pemikiran Islam paling tidak dapat dilihat dari adanya perbedaan tentang keberlakuan hasil rukyah. Hal ini bermula dari perbedaan apabila hilal berhasil dirukyah di suatu kawasan, maka apakah hasil rukyah di kawasan tersebut berlaku untuk seluruh umat Islam yang ada di seluruh dunia ataukah hanya diberlakukan untuk kaum muslim di kawasan tempat keberhasilan rukyah tersebut saja.

Kata matla’ secara bahasa berasal dari ta-la- 'a (طلع (ط) yang artinya terbit, muncul, keluar (Munawwir, 1984: 921). Kata ini kemudian dapat dibentuk menjadi matli' (مطلع) dengan 
huruf lam yang dikasrah dan matla' (مطلع) dengan huruf lam yang difathah yang memiliki makna yang berbeda. Kata bentukan pertama (matli) bermakna tempat munculnya bulan, bintang, atau matahari sedangkan kata bentukan kedua (matla) bermakna waktu atau zaman munculnya bulan, bintang, atau matahari. Makna ini dapat dilihat dalam al-Qur'an surat alKahf ayat 90 dan al-Qadar ayat 5:

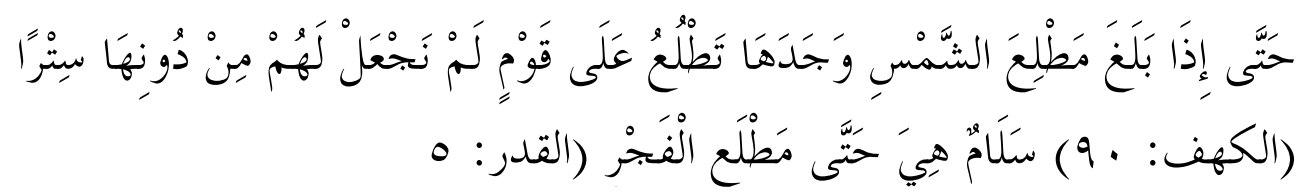

Mengenai keberlakuan matla' ini para ulama, apabila dilacak pada literatur klasik diantaranya Fath al-Bäri (al-'Asqalani, 1977: IV/123) Nail al-Autāar (asy-Syaukani t.t.: IV/267), Tubfah alAbwa zi (al-Mubarakfuri, t.t.: III/308) terbagi dalam dua pandangan. Pertama, pendapat Jumhur Ulama madzhab Hanafi, Maliki, dan Hambali. Mereka berpendapat bahwa rukyah di suatu negeri berlaku untuk seluruh kaum muslimin di negeri-negeri yang lain, sehingga adanya perbedaan matla' (ikhtiläf al-matāali) tidak memiliki pengaruh apapun terhadap penentuan masuknya bulan baru hijriah. Pendapat kedua adalah pendapat Imam asy-Syafi'i dan sejumlah ulama salaf yang berpendapat bahwa penentuan awal bulan hijriyah memperhitungkan perbedaan matla' sehingga masing-masing negeri penetapan awal bulan didasarkan kepada hasil pengamatan hilal di negerinya sendiri (al-Zuhaili, 1996: II/605).

Kelompok pertama yang menjadikan satu dunia dalam satu kesatuan dalam penentuan awal bulan kamariah (kesatuan matla' atau ittifäq/ittihäa d al-matäli) mendasarkan pendapatnya pada keumuman hadis tentang perintah puasa. Hadis yang memerintahkan untuk memulai puasa ditujukan untuk seluruh umat Islam di seluruh penjuru dunia. Jika ada kesaksian hilal dapat dirukyah di satu tempat, maka kesaksian itu diberlakukan untuk seluruh umat Islam di dunia tanpa membedakan perbedaan negara dan wilayah (al-Syaukani, t.t: IV/267, al-Zuhaili, 1996, II/609).

Sedangkan kelompok kedua mendasarkan pendapatnya pada hadis Kuraib tentang tidak dipakainya keberhasilan rukyah Mu'awiyah yang ada di Syam oleh Ibnu 'Abbas yang saat itu berada di Madinah. 


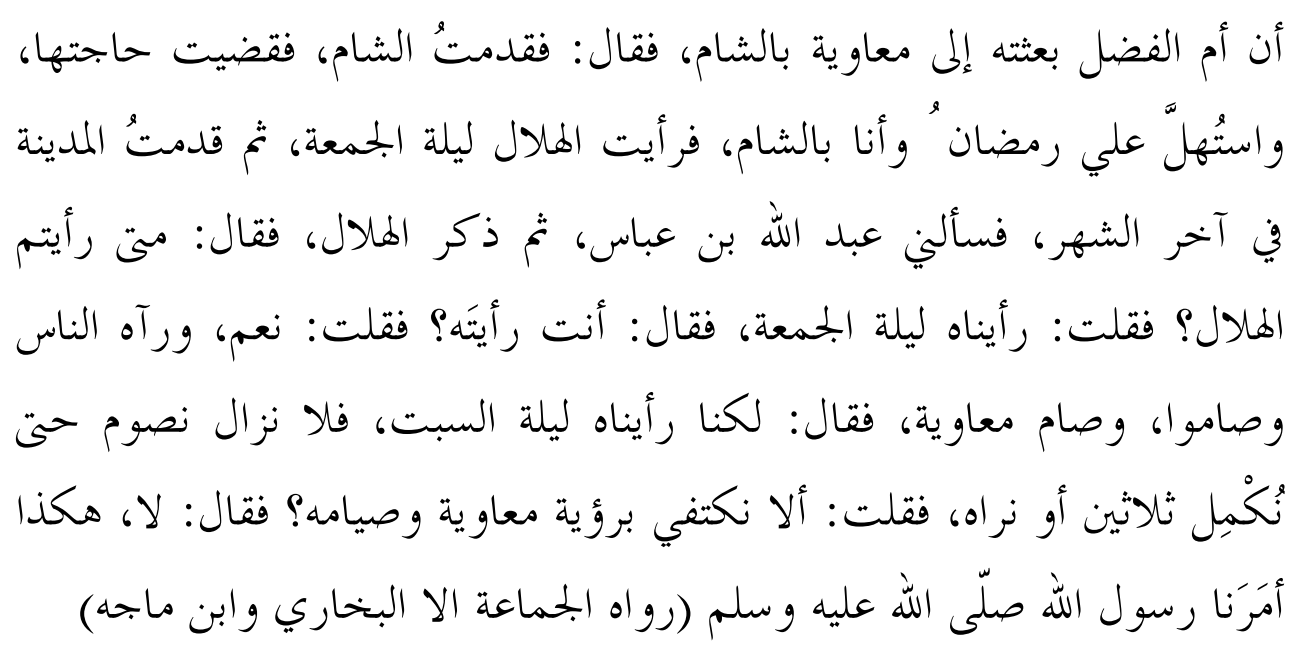

Hadis ini memberikan pengertian bahwa Ibnu 'Abbas yang berada di Madinah, yang berbeda matla’ dengan Syam, tidak menerima hasil rukyah Mu'awiyah karena perbedaan jarak yang jauh antara kedua tempat tersebut. Perkataan Ibnu 'Abbas "Tidak, demikianlah Rasulullah saw. memerintabkan kita" dalam hadis tersebut menjadi dalil bahwa setiap negeri harus mengikuti hasil rukyatnya sendiri-sendiri, dan hasil rukyat suatu negeri tidak berlaku untuk negeri yang lain karena ada perbedaan matla' (li ikhtiláf matäli) (al-Mubarakfuri, t.th.: III/308).

Selain itu, ada juga yang berpendapat bahwa apabila wilayahnya saling berdekatan, maka keberhasilan rukyah tersebut dapat ditransfer ke wilayah yang lain. Sedangkan apabila berjauhan, maka sebagian ulama tetap membolehkan transfer rukyah, sedangkan sebagian yang lain melarangnya.

Ukuran jauh dan dekatnya satu wilayah ke wilayah yang lain, para ulama juga berbeda pendapat. Diantara pendapat-pendapat tersebut; pertama, dengan melihat perbedaan matla' Apabila dua wilayah masih dalam satu matla', maka dianggap sebagai wilayah yang berdekatan. Dan dikatakan berjauhan apabila di luar wilayah tersebut. Kedua, masāfah al-qasr, jarak yang diperbolehkan untuk melakukan salat qasar. Ketiga, perbedaan iqlim, dan keempat adalah berdasar pada perbedaan kedua wilayah dari sisi tinggi rendah geografis, seperti antara wilayah pegunungan dan dataran rendah, yang menjadikan satu wilayah lebih mudah dalam melihat hilal dibanding wilayah yang lain. 
Keempat ukuran jarak diberlakukannya hasil rukyah tersebut memang masih perlu diperdebatkan landasan normatifnya, masih menimbulkan berbagai penafsiran dari sisi hakikatnya selain membutuhkan "penerjemahan" yang tepat ke dalam perhitungan matematis kontemporer.

Mengenai batas satu matla', Abd. Salam Nawawi (2004: 106-111) berusaha melakukan perhitungan sederhana (kira-kira/taqribī) batas matla'ke arah Timur dari pusat observasi atau markaz rukyah dengan memperhitungkan kecepatan gerakan Bumi pada porosnya, kecepatan gerakan Bulan mengelilingi Bumi, dan kecepatan gerakan semu Matahari di sepanjang lingkaran ekliptika. Dari hasil perhitungan faktor-faktor tersebut, ia mengatakan bahwa batas matla'ke arah Timur dari markaz rukyat dapat dihitung dengan salah satu dari dua rumus:

a. Derajat irtifa' (ketinggian) hilal dikurangi derajat batas visibilitas hilal, dibagi $0^{\circ} 30^{\circ} 28,6^{\prime \prime}$, lalu dikalikan 15

b. Derajat irtifa' (ketinggian) hilal dikurangi derajat batas visibilitas hilal, lalu dikalikan $29^{\circ} 31^{\prime} 50,84^{\prime \prime}$.

Untuk pusat observasi hilal Jakarta, misalnya, jika diketahui bahwa ketinggian hilalnya $3^{\circ} 6^{\prime}$, sedangkan batas visibilitas hilalnya -misalnya- $2^{\circ}$, maka batas matla' ke arah Timur dari markaz tersebut adalah $\left(3^{\circ} 6^{\circ}-2^{\circ}\right): 0^{\circ} 30^{\circ} 28,6^{\prime \prime}$ x $15=32^{\circ} 29^{\circ} 1,92^{\prime \prime}$. Jadi, batas matla' di sebelah Timur markaz rukyah Jakarta (bujur 106 49 ) adalah 139¹8‘1,92" yang hamper mencapai Merauke atau sekitar $3.585 \mathrm{~km}$ (hasil dari 32²9`1,92" x (111 km x cosines $6^{\circ} 10^{\circ}$ (lintang Jakarta). Batas matla' ini akan lebih panjang apabila batas visibilitas hilal yang dijadikan patokan lebih kecil dari $2^{\circ}$ dan akan lebih pendek apabila batas visibilitas hilalnya lebih besar dari $2^{\circ}$. Wahbah al-Zuhaili (1996: II/ 607) mengatakan bahwa 1 matla' setara dengan 24 farsakh. Jika 1 farsakh adalah 3 mil, maka 1 matla' adalah 24 x 3 x 1,6093 km =115,8696 km. Akan tetapi jika 1 farsakh adalah $5544 \mathrm{~m}$, maka 1 matla' adalah 133,056 km.

Jarak masāafah al-qaṣr menurut Wahbah al-Zuhaili (1996: II/607) adalah 4 barid atau 16 farsakh. Jika 1 farsakh $5544 \mathrm{~m}$, maka jarak tersebut adalah 16 x $5544=88,704 \mathrm{~km}$. Akan tetapi, jika 1 farsakh adalah 3 mil, maka jarak tersebut menjadi 1,6093 $\mathrm{km}$ x 3 × $16=$ 77,2464 km. Sedangkan Zubair 'Umar al-Jailani (t.t.: 203) mengatakan bahwa masäafah al-qaṣr adalah 89,05920 km karena 1 mil dalam pandangannya adalah 1855,40 m. 
Dengan munculnya konsep negara bangsa (nation state) di masa ini, maka ukuran-ukuran tersebut dapat memunculkan berbagai masalah. Jika ukuran keberlakuan hasil rukyah diberlakukan sejauh matla'sebagaimana definisi di atas, maka sebuah negara yang memiliki wilayah yang luas seperti Indonesia akan memiliki beberapa matla’. Begitu juga dengan ukuranukuran yang lain. Oleh karena itulah kemudian muncul konsep matla' fí wilayah al-huk.m (wilayatul hukmi/wilayah pemerintahan negara) yang memberlakukan keberhasilan rukyah pada sebuah pemerintahan negara bangsa. Ukuran matla' fi wilayah al-hukkm (wilayatul hukmi) inipun akhirnya bersifat sangat relatif, mengikuti sempit dan luasnya wilayah suatu negara.

\section{Pemikiran M. S. Odeh tentang ragam penyatuan matla'}

Saat berbicara tentang konsep perbedaan dan penyatuan matla' dalam pandangan para ulama fikih, harus dipahami bahwa perbedaan pendapat tersebut ssangat tergantung pada tingkat pengetahuan dan pemahaman mereka dengan persoalan ilmu falak. Argumentasi yang disampaikan untuk menguatkan pandangan dan menolak pandangan ulama lain yang berbeda pendapat juga beragam sesuai dengan kemampuan mereka dalam persoalan ilmu falak. Oleh karena itu, ada beberapa argumentasi atas pendapat yang berkaitan dengan tema matla' terkadang tidak berkaitan sama sekali dengan persoalan astronomi dan ilmu falak.

Oleh karena itulah, menurut Odeh (2012: 8), pemahaman atas permasalahan astronomi menjadi sangat penting agar pendapat fikih yang berkaitan dengan tema astronomi seperti persoalan matla' tidak terlalu jauh dengan kenyataan-kanyataan ilmiah astronomis. Secara astronomis, menurut Odeh (2012: 8-11), tema perbedaan matla', apabila dikaitkan dengan observasi (rukyah) hilal, dapat dilihat dari tiga poin:

a. Kondisi rukyah hilal berbeda sesuai perbedaan garis bujur (pergerakan ke arah utara dan selatan). Artinya, wilayah yang berada dalam satu garis bujur tidak bisa dikatakan memiliki matla' yang sama. Matahari dan hilal akan berada pada waktu terbenam yang berbeda walaupun berada pada satu garis bujur. Oleh karena itu, hilal bisa saja mustahil dilihat di satu wilayah, akan tetapi mudah dilihat di wilayah yang lain yang memiliki garis lintang yang sama akan tetapi berbeda garis bujurnya.

b. Kondisi rukyah hilal berbeda sesuai perbedaan garis lintang (pergerakan ke arah barat dan timur). Hampir sama dengan point pertama, wilayah yang berada dalam satu garis 
lintang juga tidak bisa dikatakan memiliki matla'yang sama. Hilal bisa saja mustahil dilihat di satu wilayah, akan tetapi mudah dilihat di wilayah yang lain yang memiliki garis bujur yang sama akan tetapi berbeda garis lintangnya.

c. Ketinggian lokasi observasi dari permukaan air laut harus diperhatikan saat rukyah. Ketika seseorang melakukan observasi, maka ketinggian tempat observasi dari permukaan air laut sangat mempengaruhi keberhasilan rukyah. Oleh karena itu, keberhasilan rukyah tidak bisa disamakan antara satu wilayah dengan wilayah lain dengan mengabaikan ketinggian tempat dari permukaan air laut.

Dalam perhitungan yang mengaitkan perbedaan dan kesatuan matla' dengan perhitungan ilmiah astronomis dan realitas empiris, prinsip kesatuan matla' bisa dibedakan dalam beberapa bentuk (Odeh, 2012: 15-18) di bawah ini.

\section{Kesatuan matla' secara mutlak.}

Pemikiran tentang kesatuan matla'secara mutlak ini menjadikan satu dunia dalam satu kesatuan matla' dengan prinsip transfer rukyah (naqlar-ru'yah). Apabila hilal bisa dirukyah baik dalam perhitungan (hisab) atau rukyah hakiki di daerah manapun di dunia ini, maka hari berikutnya sudah masuk bulan baru hijriah untuk seluruh dunia. Pemikiran satu matla' untuk seluruh dunia ini memang memiliki kelebihan dari sisi penyatuan kalender hijriah di seluruh dunia. Akan tetapi, prinsip ini juga menyisakan persoalan yang sangat besar. Dalam beberapa kasus, bulan baru hijriah dimulai, atas dasar prinsip kesatuan matla'secara mutlak, ketika sebagian besar wilayah di dunia masih belum terpenuhi syarat masuknya bulan baru hijriah seperti terbenamnya Bulan sebelum Matahari.

\section{Kesatuan matla’ dalam wilayah yang bersesuaian visibilitas bilalnya}

Prinsip ini menjadikan setiap wilayah yang memiliki kesesuaian visibilitas hilal dalam satu kesatuan matla'. Artinya, pembagian matla' didasarkan pada kemungkinan dilihat atau tidaknya hilal. Jika hilal mungkin untuk dilihat, maka pembagian tetap dilakukan dengan melihat apakah kemungkinan tersebut dengan memakai mata tanpa alat ataukah dengan alat. 


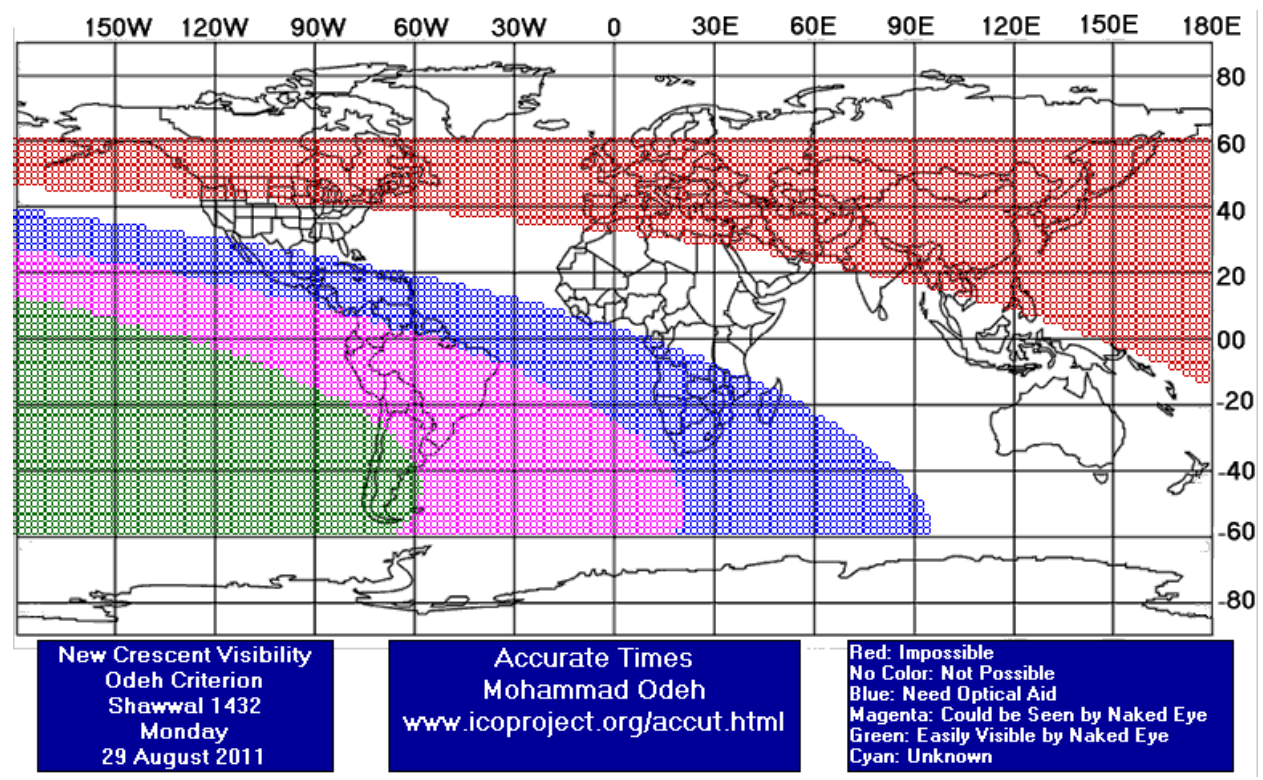

Peta Visibilitas Hilal

Pada gambar di atas wilayah-wilayah yang berada di warna hijau, wilayah yang hilal mudah untuk dilihat dengan mata tanpa alat, dijadikan sebagai wialayah dalam satu kesatuan matla' terlepas dari dekat dan jauhnya wilayah-wilayah tersebut. Begitu juga wilayah-wilayah yang berada di warna ungu (hilal mungkin dilihat dengan mata tanpa alat jika kondisi mendukung), berada di warna biru (hilal hanya dapat dilihat dengan alat optik) berada dalam satu kesatuan matla'.

Prinsip ini memiliki kelebihan karena menjadikan perhitungan astronomis (visibilitas hilal) yang detail, sesuai dengan kemungkinan dilihatnya hilal, sebagai dasar kesatuan matla'. Hanya saja, karena visibilitas hilal itu selalu berubah di setiap bulan, maka wilayah-wilayah yang berada dalam satu kesatuan matla'juga akan mengalami perubahan setiap bulannya. Dua atau tiga negara bisa menjadi satu matla' di bulan ini misalnya, akan tetapi bisa menjadi berbeda matla' di bulan depan. Hal ini tentu akan membuat kesulitan untuk pembentukan sebuah kalender (Odeh, 2012: 15). 
ljtihad, Jurnal Wacana Hukum Islam dan Kemanusiaan, Vol. 12, No. 2, Desember 2012: 179-192

\section{Kesatuan matla' dalam wilayah yang serupa visibilitas bilahya}

Prinsip ini menjadikan wilayah-wilayah yang serupa visibilitas hilalnya dalam satu kesatuan matla'. Dalam gambar di atas, wilayah-wilayah yang berada pada warna hijau, ungu, dan biru dijadikan satu mațla'karena semuanya merupakan wilayah yang hilal mungkin untuk dirukyah baik dengan alat optik maupun dengan mata tanpa alat. Sedangkan wilayah tanpa warna dan warna merah berada pada matla' yang lain, yaitu mațla' yang hilal tidak mungkin dan mustahil dirukyah. Dengan demikian, pemikiran ini membagi dunia dalam dua matla, yaitu wilayah yang hilal mungkin dirukyah dan wilayah yang hilal tidak mungkin atau mustahil dirukyah.

Pemikiran ini memiliki kelebihan dari sisi adanya wilayah yang lebih besar dan luas yang berada dalam satu kesatuan matla'. Akan tetapi, pemikiran ini juga tidak secermat pemikiran poin ke-2 karena tidak membedakan antara wilayah yang hilal mudah dilihat dengan mata tanpa alat dengan wilayah yang hilal hanya dapat dilihat dengan perangkat binokuler saja. Selain itu, seperti pemikiran sebelumnya, wilayah yang berada dalam satu matla' pun akan selalu berubah sesuai perubahan visibilitas hilal (Odeh, 2012: 16).

Kesatuan matla’ parsial/ zonal (jur'īi)

Pemikiran ini membagi dunia dalam zona-zona tertentu, baik dua zona, tiga zona maupun empat zona, dimana setiap zona adalah dalam satu kesatuan matla'. Apabila perhitungan atau rukyah faktual menunjukkan bahwa hilal dapat dirukyah pada satu zona, maka bulan baru hijriah akan dimulai di zona tersebut.

Pemikiran penyatuan parsial atau zonal ini memiliki kekurangan dari sisi masih mungkin terjadinya perbedaan dalam memulai bulan baru hijriah walaupun maksimal perbedaan yang terjadi dalam ini hanya satu hari. Artinya, walaupun pembagian zona yang terjadi adalah tiga atau empat zona, perbedaan yang mungkin terjadi tetap hanya satu hari. Semakin banyak zona yang ada, maka tingkat ketelitian dalam memperhitungkan kemungkinan kenampakan hilal akan semakin tinggi. Akan tetapi, terbaginya zona di dunia dalam tiga atau empat zona membawa dampak pada kemungkinan tidak bersatunya dunia Islam dalam satu permulaan bulan baru hijriah, sehingga tidak akan dapat menciptakan sebuah kesatuan dalam kalender hijriah (Odeh, 2012: 18). 
Dan hal inilah yang menjadi keunggulan pembagian dunia dalam dua zona. Jika pada suatu saat hilal hanya dapat dilihat dari zona Barat dan tidak dapat dilihat dari zona Timur yang menjadikan adanya perbedaan dalam memulai bulan baru hijriah, sebagian besar dunia Islam yang berada di zona Timur tetap akan memulai bulan baru hijriah secara bersamaan. Artinya, akan ada "kesatuan" di sebagian besar dunia Islam yang menjadikan sebagian besar umat Islam akan memasuki bulan baru hijriah secara bersamaan.

\section{Kesatuan matla' lokal (al-mahalīi)}

Kesatuan matla' lokal inilah yang dipakai sebagian besar kalender hijriah di dunia Islam, yakni menjadikan batas-batas negara secara politik sebagai batasan dalam keberlakuan rukyah atau yang lebih dikenal dengan kesatuan dalam wilayah hukum (matla' fī wilayah al-ḥukm). Matla' akan berbeda-beda dari sisi luas dan sempitnya sesuai dengan luas dan sempitnya batasan sebuah negara. Dan kesatuan matla' hanya terbatas pada luas sebuah negara.

\section{Penutup}

Pemikiran Odeh tentang ragam pembagian matla' bisa dikatakan sebagai sebuah pemikiran yang baru tentang konsep matla' karena memberikan sentuhan perhitungan astronomis yang lebih besar dibandingkan pemikiran-pemikiran tentang matla' sebelumnya yang banyak dihubungkan dengan konsep-konsep geografis semata (semisal satu wilayah iklim, tinggi rendah wilayah) atau bahkan dihubungkan dengan konsep lain yang tidak memiliki hubungan sama sekali dengan persoalan astronomis (semisal masäfah al-qașr). Ragam penyatuan matla' yang disampaikan Odeh juga lebih rinci dibandingkan pemikiran lain yang hanya membagi penyatuan matla' pada matla' global dan matla' 'fí wilayah al-ḥukmi.

Pada akhirnya, persoalan penyatuan awal bulan hijriah yang diinginkan juga harus melihat pada penyatuan matla' yang akan dianut. Jika penyatuan yang diinginkan adalah pada tingkat nasional, wilayah dalam satu negara, maka matla' yang dipakai adalah matla' $\bar{f}$ wilayah albukmi, jika yang diinginkan adalah penyatuan di sebagian besar dunia Islam, maka matla' yang dipakai adalah matla' jur $\bar{i}$ (zonal), dan jika yang diinginkan adalah penyatuan awal bulan hijriah secara global, maka penyatuan matla' yang dianut adalah matla' global. Dan masingmasing pemikiran memiliki keunggulan dan kelebihannya. 
ljtihad, Jurnal Wacana Hukum Islam dan Kemanusiaan, Vol. 12, No. 2, Desember 2012: 179-192

\section{Daftar pustaka}

Al-Amin, M. Fuad. Mohammad Odeh dan Upaya Penyatuan Kalender Islam, diakses dari http:// qamazaidun.blogspot.com/2008_03_01_archive.html tanggal 8 Maret 2009.

Al-AAsqalani. Fath al-Bārì̀. Beirut: Dār al-Ma’rifah, 1977.

Azhari, Susiknan. Ilmu Falak, Perjumpaan Khazanah Islam dan Sains Modern. Yogyakarta: Suara Muhammadiyah, 2007.

Ichtijanto (ed.). Almanak Hisab Rukyat. Jakarta: Proyek Pembinaan Badan Peradilan Agama Islam, 1981.

Al-Jailani, Zubair 'Umar. al-Khulasah al-Wafiyyah fi al-Falak bi Jadawil al-Lugharitmiyyah. Kudus, Menara Kudus, t.th.

Al-Mubarakfuri. Tubfah al-Ahwažri. Beirut: Dār al-Kutub al-'Ilmiyyah, t.th.

Munawwir, A. Warson. Kamus al-Munawnir, Yogyakarta: Pustaka Progresif, 1984.

Nawawi, Abd. Salam. Rukyat Hisab di Kalangan NU Mubammadiyah, Meredam Konflik dalam Menetapkan Hilal. Surabaya: Diantama bekerjasama dengan LFNU Jatim, 2004.

Odeh, Mohammad Shawkat. Taqwim Nasb al-Khata' fi Taḥdid Awäil al-Asyhur al-Hijriyyah (fi al-Urdun) diakses dari www.icoproject.org tanggal 28 April 2009.

Odeh, Mohammad Shawkat. Ikbtilāaf al-Matāili', al-Manātiq al-Musytarakah bi Matla' Wähịid, makalah pada al-Mu'tamar al-'̄Alamì li I'sbät asy-Syubür al-Qamariyyah 'inda 'Ulamā' asySyari'ah wa al-Hisäb al-Falakì yang diadakan oleh Komite Fiqh Islam (al-Majma' al-Fiqhì al-Islā mi) OKI (Räbitah al-'̄Alam al-Islämì di kantor OKI, Mekah, pada tanggal 19-21/ 03/1433 H/11-13/02/2012 M.

al-Syaukani. Nail al-Auțār. Beirut: Dār al-Fikr, t.th.

Tim Majelis Tarjih dan Tajdid PP Muhammadiyah. Pedoman Hisab Muhammadiyah. Yogyakarta: Majelis Tarjih dan Tajdid PP Muhammadiyah, 2009.

Al-Zuhaili, Wahbah. Al-Fiqh Al-Islami wa Adillatuhu. Damaskus: Dār al- Fikr, 1996. 